\title{
Performance of 'Rocha' and 'Santa Maria' pears as affected by planting density
}

\author{
Mateus da Silveira Pasa(1), José Carlos Fachinello(2), Horacy Fagundes da Rosa Júnior ${ }^{(2)}$, \\ Émerson De Franceschi(2), Juliano Dutra Schmitz ${ }^{(2)}$ and André Luiz Kulkamp de Souza ${ }^{(3)}$
}

\begin{abstract}
(1)Empresa de Pesquisa Agropecuária e Extensão Rural de Santa Catarina (Epagri), Estação Experimental de São Joaquim, Rua João Araújo Lima, no 102, Jardim Caiçara, CEP 88600-000 São Joaquim, SC, Brazil. E-mail: mateuspasa@epagri.sc.gov.br (2)Universidade Federal de Pelotas, Departamento de Fitotecnia, Caixa Postal 354, CEP 96010-900, Pelotas, RS, Brazil. E-mail: jfachi@ufpel.tche.br, horacyf@gmail.com, emersondefranceschi@gmail.com, jdsagro@gmail.com ${ }^{(3)}$ Epagri, Estação Experimental de Videira, Rua João Zardo, № 1.660, Campo Experimental, CEP 89560-000 Videira, SC, Brazil. E-mail: andresouza@epagri.sc.gov.br
\end{abstract}

\begin{abstract}
The objective of this work was to evaluate the performance of 'Rocha' and 'Santa Maria' pears at two planting densities. The experiment was carried out during the 2011/2012, 2012/2013, and 2013/2014 growing seasons, in one-year-old orchards (2011/2012) of 'Rocha' and 'Santa Maria' pears, trained in a central-leader system and planted in two densities (2,000 and 4,000 trees per hectare). The assessed parameters were: production per hectare, production per tree, yield efficiency, number of fruit per tree, average fruit weight, trunk diameter increment, fruit firmness, and soluble solid contents. The cumulative yield of 'Rocha' is greater at the higher planting density, whereas the yield efficiency of 'Santa Maria' increases at the lower planting density, as the trees get more mature. Trunk diameter of 'Rocha' also increases at the lower planting density. However, fruit quality parameters in both cultivars are little affected by planting density.
\end{abstract}

Index terms: Pyrus communis, fruit quality, spacing, yield.

\section{Desempenho das pereiras 'Rocha' e 'Santa Maria' de acordo com a densidade de plantio}

\begin{abstract}
Resumo - O objetivo deste trabalho foi avaliar o desempenho das pereiras 'Rocha' e 'Santa Maria' em duas densidades de plantio. O experimento foi realizado nos anos agrícolas 2011/2012, 2012/2013 e 2013/2014, em pomares de um ano de idade (2011/2012) de pereiras 'Rocha' e 'Santa Maria', conduzidos em líder central e plantados em duas densidades (2.000 e 4.000 plantas por hectare). Os parâmetros avaliados foram: produção por hectare, produção por planta, eficiência produtiva, número de frutas por planta, massa média de fruta, incremento de diâmetro de tronco, firmeza de polpa e teores de sólidos solúveis. A produção acumulada de 'Rocha' é maior na maior densidade de plantio, enquanto a eficiência produtiva de 'Santa Maria' aumenta na menor densidade de plantio, à medida que as plantas se tornam mais maduras. O diâmetro de tronco de 'Rocha' também aumenta na menor densidade de plantio. No entanto, os parâmetros de qualidade de fruta em ambas as cultivares são pouco afetados pela densidade de plantio.
\end{abstract}

Termos para indexação: Pyrus communis, qualidade de fruta, espaçamento, produtividade.

\section{Introduction}

Pear (Pyrus communis L.) production is still incipient in Brazil, which produces approximately $10 \%$ of the pears consumed in the domestic market. The lack of adequate chilling, i.e., quantity and quality, during the dormancy period, the need for adapted cultivars and rootstocks, and insufficient knowledge about orchard management are the main responsible factors for this situation (Pasa et al., 2012). Among these problems, there is a greater lack of information on the latter, regarding, for instance, planting density. According to Policarpo et al. (2006), increasing planting density is a powerful tool to increase fruit yield and orchard efficiency.

Pear production in Brazil is characterized by low density orchards grafted mainly onto vigorous rootstocks, such as $P$. calleryana, which have low early production (Pasa et al., 2012). In order to overcome this difficulty, more efficient and profitable systems, including high-density planting, might be used. These orchards offer the advantages of early production, sustained high yields of high-quality fruit, and lower labor costs (Hampson et al., 2002). If high 
early production could be achieved, pears would be an attractive alternative fruit crop for fruit growers (Robinson, 2011).

Planting density is usually increased by reducing in-row distances, since light interception and mechanical operations limit the reduction of distances between rows (Policarpo et al., 2006). Increasing density up to 8,000 trees per hectare in pear orchards results in higher yields (Sansavini \& Musacchi, 2002); this performance, however, is also linked to a notable increase in planting and management costs (Sansavini et al., 2008). According to Asín et al. (2005), the planting density of 2,667 trees per hectare seems to be the most suitable system for quickly entering production, while maintaining an intermediate level of plantation costs and an appropriate level of production efficiency. Sansavini et al. (2008) suggest that the proper high-density planting threshold is of 4,000 trees per hectare, in which the density factor will depend on how practicable it may or may not be in a given situation.

The objective of this work was to evaluate the performance of 'Rocha' and 'Santa Maria' pears at two planting densities.

\section{Materials and Methods}

The study was conducted at the experimental field of Universidade Federal de Pelotas located in the municipality of Capão do Leão, in the state of Rio Grande do Sul, Brazil (31 $52^{\prime} 00^{\prime \prime} \mathrm{S}, 52^{\circ} 21^{\prime} 24^{\prime \prime} \mathrm{W}$, at $48 \mathrm{~m}$ of altitude), during the 2011/2012, 2012/2013, and 2013/2014 growing seasons. The soil of the experimental area is a Argissolo Amarelo distrófico (Ultisol), according to the Brazilian soil classification system (Santos et al., 2013). The chilling hour accumulation $\left(<7.2^{\circ} \mathrm{C}\right)$ in 2011,2012 , and 2013 was of 449, 413, and 464 hours, respectively (Embrapa, 2015). The weather conditions during the development of the experiment are described in Table 1.

Plant material consisted of one-year-old 'Santa Maria' and 'Rocha' pear trees grafted onto a low-vigor rootstock - 'Adams' (Cydonia oblonga Mill.). Those cultivars were chosen because of their potentiality in Brazilian conditions, considering their low chilling requirement ( $\sim 500$ hours). Trees were trained in a central-leader system and supported by a three-wire frame at $0.5,1.1$, and $1.7 \mathrm{~m}$ from the ground. In the field, trees were planted in two separate single rows, spaced at $5 \mathrm{~m}$ between rows and at 0.5 or $1 \mathrm{~m}$ within the row, totalizing 4,000 and 2,000 trees per hectare, respectively. Soil fertility was corrected at the beginning of the experiment based on soil analysis. Cultural practices were similar for all treatments: fertilization based on soil analysis; shoot bending; disease and pest control; weed control and drip irrigation in the summer (Pasa et al., 2012). Since orchard establishment, only light pruning was done, with water sprout removal during the summer if necessary, but no pruning of fruiting branches. At the end of the winter in 2011,2012, and 2013, at the green tip stage, trees were treated with hydrogen cyanamide $(0.2 \%)$ and mineral oil $(3 \%)$ to standardize budburst and flowering.

Trees were arranged in a randomized complete block design with four replicates of ten trees per cultivar-spacing combination. Trunk diameter was measured at $15 \mathrm{~cm}$ above the graft union with a digital caliper, at the beginning of the trial and at the end of each growing season, and expressed as trunk diameter increment in millimeters. On 1/20/2012, 1/29/2013, and $1 / 29 / 2014$, eight of the ten trees were harvested (leaving one tree at each end as a border) per replicate at commercial maturity, that is, at flesh firmness of 60-70 N. Data on yield and fruit quality of 'Santa Maria' in 2012/2013 are not presented, since there was no production in this growing season, probably due to the lower chilling accumulation observed in the winter of 2012. The total number of fruit per tree was counted and weighed $(\mathrm{kg})$. From these data, the following parameters were calculated: production per tree $(\mathrm{kg})$; average fruit size $(\mathrm{g})$; yield $\left(\mathrm{Mg} \mathrm{ha}^{-1}\right)$; and yield efficiency $\left(\mathrm{kg} \mathrm{cm}^{-2}\right)$, calculated as the reason between production per tree and trunk cross-sectional area (TCSA). TCSA was determined according to Pasa et al. (2012).

At harvest, samples of 15 fruit per replicate were placed in regular-air cold storage $\left(0 \pm 1^{\circ} \mathrm{C}\right.$; RH $\left.85 \pm 5 \%\right)$ and analyzed after 30 days for determination of fruit quality parameters. In the first growing season (2011/2012), fruit firmness was measured right after fruit were taken out of cold storage, whereas, in the other growing seasons, it was measured after fruit were left for five days at room temperature $\left(25^{\circ} \mathrm{C}\right)$ following cold storage. Fruit firmness was measured in Newton with a digital firmness tester, model 53205 (TR Di 
Turoni, Forli, Italy), using an $8 \mathrm{~mm}$ diameter probe. Sections of skin, $2 \mathrm{~cm}$ in diameter, were removed at the widest point of the fruit on opposite sides prior to the determination of fruit firmness. After fruit firmness

Table 1. Weather conditions of the experimental field located at the municipality of Capão do Leão, in the state of Rio Grande do Sul, Brazil ${ }^{(1)}$.

\begin{tabular}{|c|c|c|c|}
\hline \multirow[t]{2}{*}{ Month } & \multicolumn{2}{|c|}{ Monthly average temperature $\left({ }^{\circ} \mathrm{C}\right)$} & \multirow{2}{*}{$\begin{array}{l}\text { Monthly rainfall } \\
(\mathrm{mm})\end{array}$} \\
\hline & Minimum & Maximum & \\
\hline & & 2011 & \\
\hline May & 11.1 & 21.0 & 118.3 \\
\hline June & 8.7 & 17.7 & 116.2 \\
\hline July & 7.5 & 16.2 & 71.0 \\
\hline August & 9.2 & 17.0 & 114.2 \\
\hline September & 10.1 & 20.0 & 75.1 \\
\hline October & 13.5 & 22.1 & 75.9 \\
\hline November & 15.1 & 25.3 & 60.3 \\
\hline \multirow[t]{2}{*}{ December } & 16.2 & 26.0 & 53.7 \\
\hline & & 2012 & \\
\hline January & 17.9 & 28.4 & 73.6 \\
\hline February & 20.2 & 29.8 & 171.9 \\
\hline March & 16.6 & 28.1 & 49.0 \\
\hline April & 12.8 & 23.7 & 52.4 \\
\hline May & 12.2 & 23.9 & 5.1 \\
\hline June & 7.3 & 19.5 & 78.0 \\
\hline July & 5.6 & 16.8 & 138.5 \\
\hline August & 12.6 & 22.9 & 128.3 \\
\hline September & 12.3 & 21.3 & 115.3 \\
\hline October & 15.9 & 23.6 & 106.5 \\
\hline November & 16.6 & 27.0 & 52.1 \\
\hline \multirow[t]{2}{*}{ December } & 18.7 & 29.3 & 133.4 \\
\hline & & 2013 & \\
\hline January & 17.5 & 27.5 & 110.9 \\
\hline February & 19.1 & 28.0 & 177.3 \\
\hline March & 15.2 & 25.8 & 27.6 \\
\hline April & 13.8 & 24.5 & 147.4 \\
\hline May & 10.5 & 20.6 & 84.1 \\
\hline June & 8.0 & 18.4 & 75.8 \\
\hline July & 7.2 & 17.8 & 56.6 \\
\hline August & 7.0 & 17.1 & 95.3 \\
\hline September & 11.5 & 21.1 & 133.7 \\
\hline October & 13.5 & 22.1 & 214.0 \\
\hline November & 16.9 & 24.9 & 136.3 \\
\hline \multirow[t]{2}{*}{ December } & 18.9 & 29.2 & 78.4 \\
\hline & & 2014 & \\
\hline January & 20.6 & 30.5 & 179.6 \\
\hline February & 20.9 & 29.0 & 225.4 \\
\hline
\end{tabular}

(1)Data obtained from the weather station located at the municipality of Pelotas (Estação Agroclimatológica de Pelotas, 2015), in the state of Rio Grande do Sul, Brazil. measurements, a composite sample per replicate was juiced, and $0.5 \mathrm{~mL}$ of juice was pipetted onto a digital refractometer, model PR-32 (Atago Co., Tokyo, Japan) to determine soluble solids contents, expressed as ${ }^{\circ}$ Brix.

Data were analyzed for statistical significance, using the $\mathrm{F}$ test. The number of fruit was transformed to square root $(n+1)$. Duncan's test was performed to compare treatments when analysis of variance showed significant differences among means.

\section{Results and Discussion}

Production per hectare was greater in the higher planting density in the 2011/2012 and 2012/2013 growing seasons for 'Rocha', but only in the 2011/2012 growing season for 'Santa Maria' (Table 2). The latter variety did not produce in 2012/2013, probably due to bud abortion, since chilling accumulation in 2012 (413 hours) was lower than in the other growing seasons (449 and 464 hours in 2011 and 2013, respectively) and winter temperatures were higher (Table 1). In fact, 'Rocha' was also negatively affected in this growing season, producing less than in the previous year, when it was supposed to produce more. Cumulative yield differed only for 'Rocha', and the highest value was observed with 4,000 trees per hectare (Table 2).

Production increases obtained with a higher planting density were also reported for 'Conference' (Policarpo et al., 2006), 'Bartlett', and 'Bosc' pears (Robinson, 2011) and for 'Red Spur' apple (Pramanick et al., 2012). Increments in production per hectare are expected as planting density is increased, because of the higher number of trees capable of producing fruits. This effect was also observed by Musacchi et al. (2011) for 'Abbé Fétel' and in the present study for 'Rocha', in which cumulative production in the higher density was approximately $40 \%$ greater than in the lower planting density. As for 'Santa Maria', since no production was observed in the 2012/2013 growing season, it is not possible to conclude if the results would be similar, but yield increased in 2011/2012 in the higher planting density and there was no difference for yield between the two planting densities in 2013/2014 or for cumulative production.

Yield efficiency of 'Rocha' did not differ between planting densities in any of the growing seasons, 
whereas for 'Santa Maria' it was greater only at the lower planting density in 2013/2014 (Table 2). Production per tree differed between planting densities in 2012/2013 for 'Rocha', which was more productive at the density of 4,000 trees per hectare, and in 2013/2014 for 'Santa Maria', at 2,000 trees per hectare (Table 3). Fruit number differed significantly only for 'Santa Maria' in the 2013/2014 growing season, when fruit number was greater at the lower planting density. Average fruit weight was higher in the lower planting density for both cultivars only in the 2011/2012 growing season.

The greater production per tree observed for 'Santa Maria' in 2013/2014 in the lower planting density was probably due the higher number of fruits, since differences in average fruit weight were nonsignificant. The increase in production per tree and in yield efficiency with decreasing planting density registered for 'Santa Maria' in the 2013/2014 growing season - was also reported for 'Red Spur' apple (Pramanick et al., 2012), in which trees at the lowest planting density showed the greatest production per tree. However, opposite behavior was found for 'Forelle' pear (Plooy \& Huyssteen, 2000), 'Royal Gala' and 'McIntosh' apples (Hampson et al., 2004). This indicates that pear tree behavior in high-density plantings is genotype-dependent (Policarpo et al., 2006); therefore, each cultivar has to be tested in order to find out the most suitable planting density.

Reduction in fruit weight at higher planting densities, as observed for both cultivars in the 2011/2012 growing season, also occurred in 'Conference' (Policarpo et al., 2006), 'Bartlett', and 'Bosc' (Robinson, 2011) pears, as well as in 'Red Spur' apple (Pramanick et al., 2012), but not in 'Forelle' pear (Plooy \& Huyssteen, 2000). Musacchi et al. (2011) found a positive correlation between low planting densities and fruit weight

Table 2. Yield and yield efficiency of 'Rocha' and 'Santa Maria' pears (Pyrus communis) planted at two different in-row spacings in the 2011/2012, 2012/2013, and 2013/2014 growing seasons ${ }^{(1)}$.

\begin{tabular}{|c|c|c|c|c|c|c|c|c|}
\hline \multirow{2}{*}{$\begin{array}{l}\text { Planting density } \\
\text { (trees per hectare) }\end{array}$} & \multicolumn{3}{|c|}{ Yield $\left(\mathrm{Mg} \mathrm{ha}^{-1}\right)$} & \multirow[t]{2}{*}{ Cumulative } & \multicolumn{3}{|c|}{ Yield efficiency $\left(\mathrm{kg} \mathrm{cm}^{-2}\right)$} & \multirow[t]{2}{*}{ Cumulative } \\
\hline & $2011 / 2012$ & $2012 / 2013$ & $2013 / 2014$ & & $2011 / 2012$ & $2012 / 2013$ & $2013 / 2014$ & \\
\hline & \multicolumn{8}{|c|}{ 'Rocha' } \\
\hline 2,000 & $0.83 b$ & $0.48 b$ & 5.15 & $6.46 \mathrm{~b}$ & 0.08 & 0.03 & 0.21 & 0.32 \\
\hline 4,000 & $1.54 \mathrm{a}$ & $1.20 \mathrm{a}$ & 8.65 & $11.39 \mathrm{a}$ & 0.08 & 0.04 & 0.20 & 0.31 \\
\hline \multirow[t]{2}{*}{$\mathrm{p}$} & 0.05 & $<0.01$ & 0.06 & 0.03 & 0.92 & 0.07 & 0.62 & 0.81 \\
\hline & \multicolumn{8}{|c|}{ 'Santa Maria' } \\
\hline 2,000 & $1.00 \mathrm{~b}$ & - & 9.60 & 10.60 & 0.12 & - & $0.5 \mathrm{a}$ & 0.61 \\
\hline 4,000 & $2.48 \mathrm{a}$ & - & 8.63 & 11.11 & 0.17 & - & $0.27 \mathrm{~b}$ & 0.44 \\
\hline $\mathrm{p}$ & 0.04 & - & 0.48 & 0.73 & 0.22 & - & 0.01 & 0.09 \\
\hline
\end{tabular}

${ }^{(1)}$ Means followed by different letters within columns differ significantly according to Duncan's test, at $5 \%$ probability.

Table 3. Production per tree, number of fruit per tree, and average fruit weight of 'Rocha' and 'Santa Maria' pears (Pyrus communis) planted at two different in-row spacings in the 2011/2012, 2012/2013, and 2013/2014 growing seasons ${ }^{(1)}$.

\begin{tabular}{|c|c|c|c|c|c|c|c|c|c|}
\hline \multirow{2}{*}{$\begin{array}{l}\text { Planting density } \\
\text { (trees per hectare) }\end{array}$} & \multicolumn{3}{|c|}{ Production per tree $(\mathrm{kg})$} & \multicolumn{3}{|c|}{ Number of fruit per tree } & \multicolumn{3}{|c|}{ Average fruit weight $(\mathrm{g})$} \\
\hline & $2011 / 2012$ & $2012 / 2013$ & $2013 / 2014$ & $2011 / 2012$ & $2012 / 2013$ & $2013 / 2014$ & $2011 / 2012$ & $2012 / 2013$ & $2013 / 2014$ \\
\hline & \multicolumn{9}{|c|}{ 'Rocha' } \\
\hline 2,000 & 0.41 & $0.24 b$ & 2.57 & 3.86 & 3.76 & 20.45 & $106.25 \mathrm{a}$ & 64.62 & 127.93 \\
\hline$\underline{4,000}$ & 0.39 & $0.30 \mathrm{a}$ & 2.16 & 4.29 & 3.99 & 17.90 & $87.50 \mathrm{~b}$ & 74.66 & 120.87 \\
\hline \multirow[t]{2}{*}{$\mathrm{p}$} & 0.69 & 0.03 & 0.40 & 0.53 & 0.46 & 0.53 & 0.01 & 0.23 & 0.17 \\
\hline & \multicolumn{9}{|c|}{ 'Santa Maria' } \\
\hline 2,000 & 0.50 & - & $4.80 \mathrm{a}$ & 2.73 & - & $28.59 \mathrm{a}$ & $179.47 \mathrm{a}$ & - & 172.23 \\
\hline 4,000 & 0.62 & - & $2.15 \mathrm{~b}$ & 3.83 & - & $12.85 \mathrm{~b}$ & $169.18 \mathrm{~b}$ & - & 168.59 \\
\hline $\mathrm{p}$ & 0.29 & - & 0.01 & 0.23 & - & 0.03 & 0.05 & - & 0.80 \\
\hline
\end{tabular}

${ }^{(1)}$ Means followed by different letters within columns differ significantly according to Duncan's test, at $5 \%$ probability. 
increase. Reduction in fruit weight has been related with a higher crop load of high-density plantings (Robinson, 2011); however, fruit number did not differ among planting densities in the evaluated growing season, whereas fruit weight was negatively affected by the higher planting density. Possibly, this effect was due to less water availability on a per tree basis in the closer spacing (Policarpo et al., 2006), since irrigation was similar for both planting densities.

There was an increase in production from 2012/2013 to $2013 / 2014$, and from $2011 / 2012$ to $2013 / 2014$ for 'Rocha' and 'Santa Maria' pears, respectively, in both planting densities. This result is probably related to the adopted pruning management, which consisted in minimum pruning of the orchard since its establishment, i.e., only some water sprouts were removed when necessary in the summer, while fruiting branches were not pruned. This management was chosen because pear trees need 2-3 years to develop their main fruiting structures, the spurs (Westwood, 1987; Elkins et al., 2007). In this case, the light pruning of the trees in the first years allowed the development of these structures. Excessive vegetative growth is negatively correlated with flowering spur formation (Pasa et al., 2011), whereas the invigorating effects of pruning are well-known for pear (Pasa \& Einhorn, 2014).

Differences in trunk diameter increment were observed in the 2011/2012 and 2013/2014 growing seasons, when 'Rocha' showed greater trunk diameter in the lower planting density (Table 4). This effect was also observed in 'Conference', 'Abbé Fétel', and 'Comice' pears (Musacchi et al., 2005). A possible explanation is the suppression of tree growth by the greater production area of 'Rocha' at the higher planting density, considering fruit growth dominates over vegetative growth (Smith \& Samach, 2013). This result might also be an effect of root growth suppression at the closer spacing, as reported for 'Williams' pear (Policarpo et al., 2006). In this situation, trees would have a disadvantage on the competition for soil resources, when compared with trees at wider spacings. However, further studies are necessary to investigate the effects of planting density on root-soil interaction.

Fruit quality parameters were influenced by planting density only in the 2011/2012 growing season (Table 4). Fruit from both cultivars exhibited higher firmness at the higher planting density. A similar pattern was observed for soluble solids of 'Rocha' pear fruit. On the contrary, fruit of 'Santa Maria' showed a greater amount of soluble solids at the lower planting density. Policarpo et al. (2006) found lower fruit firmness of 'Conference' fruits as planting space was widened. A hypothesis for this result is that fruits of trees at the closer spacing were more shaded, slowing down fruit ripening. Garriz et al. (1997) reported higher firmness of shaded 'Bartlett' fruit. However, Plooy \& Huyssteen (2000) did not find differences on fruit firmness and soluble solids of 'Forelle' pear as affected by planting density. The higher soluble solids of 'Rocha' at the higher density may be attributed to the lower fruit weight, concentrating the amount of sugars. However, 'Santa Maria' did not follow this pattern. Either way, differences for both cultivars were nonsignificant and occurred in only one out of three growing seasons.

Table 4. Trunk diameter increment, fruit firmness, and soluble solids of 'Rocha' and 'Santa Maria' pears (Pyrus communis) planted at two different in-row spacings in the 2011/2012, 2012/2013, and 2013/2014 growing seasons ${ }^{(1)}$.

\begin{tabular}{|c|c|c|c|c|c|c|c|c|c|}
\hline \multirow{2}{*}{$\begin{array}{l}\text { Planting density } \\
\text { (trees per hectare) }\end{array}$} & \multicolumn{3}{|c|}{ Trunk diameter increment $(\mathrm{mm})$} & \multicolumn{3}{|c|}{ Fruit firmness $(\mathrm{N})$} & \multicolumn{3}{|c|}{ Soluble solids ( ${ }^{\circ}$ Brix $)$} \\
\hline & $2011 / 2012$ & $2012 / 2013$ & $2013 / 2014$ & $2011 / 2012$ & $2012 / 2013$ & $2013 / 2014$ & $2011 / 2012$ & $2012 / 2013$ & $2013 / 2014$ \\
\hline & \multicolumn{9}{|c|}{ 'Rocha' } \\
\hline 2,000 & $9.85 \mathrm{a}$ & 4.95 & $8.34 \mathrm{a}$ & $66.49 b$ & 49.48 & 42.88 & $12.60 \mathrm{~b}$ & 13.30 & 12.62 \\
\hline$\underline{4,000}$ & $8.78 \mathrm{~b}$ & 5.29 & $6.79 \mathrm{~b}$ & $72.36 \mathrm{a}$ & 49.14 & 40.15 & $13.05 \mathrm{a}$ & 13.43 & 12.25 \\
\hline \multirow[t]{2}{*}{$\mathrm{p}$} & 0.05 & 0.14 & 0.04 & $<0.01$ & 0.92 & 0.44 & $<0.01$ & 0.52 & 0.15 \\
\hline & \multicolumn{9}{|c|}{ 'Santa Maria' } \\
\hline 2,000 & 7.18 & 5.49 & 6.27 & $53.28 \mathrm{~b}$ & - & 23.37 & $12.60 \mathrm{a}$ & - & 10.67 \\
\hline 4,000 & 5.20 & 5.09 & 5.94 & $56.43 \mathrm{a}$ & - & 23.60 & $12.33 b$ & - & 11.62 \\
\hline $\mathrm{p}$ & 0.07 & 0.50 & 0.48 & $<0.01$ & - & 0.38 & $<0.01$ & - & 0.21 \\
\hline
\end{tabular}

${ }^{(1)}$ Means followed by different letters within columns differ significantly according to Duncan's test, at 5\% probability. 


\section{Conclusions}

1. Cumulative yield of 'Rocha' pear (Pyrus communis) is greater at the higher planting density, whereas the yield efficiency of 'Santa Maria' increases at the lower planting density, as the trees get more mature.

2. Increasing planting density reduces the trunk diameter of 'Rocha', but not of 'Santa Maria' pear.

3. Fruit weight and quality parameters in both cultivars are little affected by planting density.

\section{Acknowledgements}

To Coordenação de Aperfeiçoamento de Pessoal de Nível Superior (Capes) and to Conselho Nacional de Desenvolvimento Científico e Tecnológico (CNPq), for financial support.

\section{References}

ASÍN, L.; MONTSERRAT, R.; CARBÓ, J.; VILARDELL, P.; CARRERA, M. Comparison of the yield, labour requirement and fruit quality of 'Conference' pears under five intensive training systems in Spain. Acta Horticulturae, v.671, p.455-461, 2005.

ELKINS, R.B.; VAN DEN ENDE, B.; BEUTEL, J. Vegetative growth and fruit development. In: MITCHAM, E.; ELKINS, R. (Ed.). Pear production and handling manual. Oakland: University of California, 2007. p.51-76.

EMBRAPA. Monitoramento do acúmulo de horas de frio na Região de Pelotas. Disponível em: $<$ http://www.cpact.embrapa.br/ agromet/online/Horas_Frio.htm>. Acesso em: 5 jan. 2015.

ESTAÇ̃̃O AGROCLIMATOLÓGICA DE PELOTAS (Capão do Leão). Boletim Agroclimatológico. 2015. Disponível em: $<$ http:// www.cpact.embrapa.br/agromet/estacao/boletim.php>. Acesso em: 5 jan. 2015.

GARRIZ, P.I.; ALVAREZ, H.L.; ALVAREZ, A.J. Influence of altered irradiance on fruits and leaves of mature pear leaves. Biologia Plantarum,v.39,p.229-234, 1997.DOI: 10.1023/A:1000344920479.

HAMPSON, C.R.; QUAMME, H.A.; BROWNLEE, R.T. Canopy growth, yield, and fruit quality of 'Royal Gala' apple trees grown for eight years in five tree training systems. HortScience, v.37, p.627-631, 2002.

HAMPSON, C.R.; QUAMME, H.A.; KAPPEL, F.; BROWNLEE, R.T. Varying density with constant rectangularity: II. Effects on apple tree yield, fruit size, and fruit color development in three training systems over ten years. HortScience, v.39, p.507-511, 2004.

MUSACCHI, S.; ANCARINI, V.; GAMBERINI, A.; GADDONI, M.; GRANDI, M.; SANSAVINI, S. Response of training system, planting density and cultivar in pear. Acta Horticulturae, v.671, p.463-469, 2005.

MUSACCHI, S.; SERRA, S.; ANCARINI, V. Comparison among pear training systems and rootstocks for high density planting (HDP) of the cultivar 'Abbé Fétel'. Acta Horticulturae, v.909, p.251-258, 2011.

PASA,M.S.;EINHORN,T.C.Heading cutsandprohexadione-calcium affect the growth and development of 'd'Anjou' pear shoots in a high-density orchard. Scientia Horticulturae, v.168, p.267-271, 2014. DOI: 10.1016/j.scienta.2014.02.003.

PASA, M. da S.; FACHINELLO, J.C.; SCHMITZ, J.D.; SOUZA, A.L.K. de; FRANCESCHI, É. de. Desenvolvimento, produtividade e qualidade de peras sobre porta-enxertos de marmeleiro e Pyrus calleryana. Revista Brasileira de Fruticultura, v.34, p.873-880, 2012. DOI: 10.1590/S0100-29452012000300029.

PASA, M. da S.; FACHINELLO, J.C.; SCHMITZ, J.D.; SOUZA, A.L.K. de; HERTER, F.G. Hábito de frutificação e produção de pereiras sobre diferentes porta-enxertos. Pesquisa Agropecuária Brasileira, v.46, p.998-1005, 2011. DOI: 10.1590/ S0100-204X2011000900005.

POLICARPO, M.; TALLUTO, G.; LO BIANCO, R. Vegetative and productive responses of 'Conference' and 'Williams' pear trees planted at different in-row spacings. Scientia Horticulturae, v.109, p.322-331, 2006. DOI: 10.1016/j.scienta.2006.06.009.

PLOOY, P. du; HUYSSTEEN, P. van. Effect of BP1, BP3, and Quince A rootstocks, at three planting densities, on precocity and fruit quality of 'Forelle' pear (Pyrus communis L.). South African Journal of Plant and Soil, v.17, p.57-59, 2000. DOI: 10.1080/0257 1862.2000.10634867.

PRAMANICK, K.K; KISHORE, D.K.; SINGH, R.; KUMAR, J. Performance of apple (Malus x domestica Borkh) cv. Red Spur on a new apple rootstock in high density planting. Scientia Horticulturae, v.133, p.37-39, 2012. DOI: 10.1016/j.scienta.2011.10.009.

ROBINSON, T.L. High density pear production with Pyrus communis rootstocks. Acta Horticulturae, v.909, p.259-270, 2011.

SANSAVINI, S.; ANCARANI, V.; NERI, D. Overview of intensive pear culture: planting density, rootstocks, orchard management, soil-water relations and fruit quality. Acta Horticulturae, v.800, p.35-50, 2008.

SANSAVINI, S.; MUSACCHI, S. European pear orchard design and HDP management: a review. Acta Horticulturae, v.596, p.589-601, 2002.

SANTOS, H.G. dos; JACOMINE, P.K.T.; ANJOS, L.H.C. dos; OLIVEIRA, V.A. de; LUMBRERAS, J.F.; COELHO, M.R.; ALMEIDA, J.A. de; CUNHA, T.J.F.; OLIVEIRA, J.B. de. Sistema brasileiro de classificação de solos. 3.ed. rev. e ampl. Brasília: Embrapa, 2013.

SMITH, H.M.; SAMACH, A. Constraints to obtaining consistent annual yields in perennial tree crops. I: Heavy fruit load dominates over vegetative growth. Plant Science, v.207, p.158-167, 2013. DOI: 10.1016/j.plantsci.2013.02.014.

WESTWOOD, M.N. Temperate-zone pomology: physiology and culture. Portland: Timber Press, 1987. 428p.

Received on July 22, 2014 and accepted on January 13, 2015 